\title{
EDITORIAL
}

\section{APRESENTAÇÃO DA EDIÇÃo}

Com satisfação apresento à comunidade acadêmica o segundo número do sexto volume da revista Organizações e Sustentabilidade.

No primeiro artigo, de título "De Onde vem esse Currículo? A Educação Sustentável nos cursos de Administração", Alves e Nascimento (2018) promoveram reflexões sobre as possibilidades para alterações nos currículos dos cursos de Administração.

No segundo artigo, de título "O Ensino de Sustentabilidade nas Ciências Econômicas: Perspectiva Crítica e Elementos Norteadores do Debate", Andrade e Lima (2018) discutiram a forma com a qual o debate sobre desenvolvimento sustentável é conduzido pelas ciências econômicas.

No terceiro artigo, de título "Sustentabilidade organizacional na Itaipu Binacional: uma análise de seus niveis" Cappelari et al. (2018) buscaram compreender os niveis de sustentabilidade organizacional na Itaipu Binacional.

No quarto artigo, de título "Sustentabilidade Ambiental, Econômica e Social: Ações e Práticas de Pequenas e Médias Empresas Brasileiras", Jhunior e Vilela (2018) identificaram as ações e práticas de sustentabilidade ambiental, econômica e social adotadas pelas pequenas e médias empresas (PMEs) brasileiras.

No quinto artigo, de título "Redes para a Sustentabilidade: Estudos de Caso sobre o Manejo dos Resíduos Sólidos no Brasil", Damico et al. (2018) apresentaram dois estudos de caso de empresas no Brasil que se organizam a partir de redes para o manejo e aproveitamento sustentável de resíduos sólidos.

No sexto artigo, de título "Práticas de Saúde e Segurança do Trabalho (SST) na área de Manufatura: um modelo teórico" Maia et al. (2018) retrataram um conjunto de constructos relacionados sobre as práticas de saúde e segurança no trabalho com o objetivo de apresentar um modelo teórico.

Boa leitura a todos!

\section{Rafael Borim-de-Souza Editor-Chefe}

